\title{
Micropropagation and HPLC-DAD, UPLC MS/MS analysis of oenothein $B$ and phenolic acids in shoot cultures and in regenerated plants of fireweed (Chamerion angustifolium (L.) Holub)
}

\author{
Mariola Dreger $^{1} \mathbb{D} \cdot$ Agnieszka Gryszczyńska $^{2} \cdot$ Milena Szalata $^{1} \cdot$ Karolina Wielgus $^{1}$
}

Received: 4 May 2020 / Accepted: 12 October 2020 / Published online: 19 October 2020

(c) The Author(s) 2020

\begin{abstract}
In this study, a micropropagation protocol using nodal explants from in vitro grown plants of Chamerion angustifolium (L.) Holub was developed and analysis of oenothein B and selected phenolic acids in shoot cultures was performed for the first time. For shoot induction and multiplication Murashige and Skoog's (MS) basal medium supplemented with 2-isopentenyladenine (2iP), zeatin $(\mathrm{Z})$ and 6-benzyloaminopurine (BAP) was used. 2iP was the most responsive in terms of promoting shoots per explant with the maximum $(6.57 \pm 1.14)$ recorded at a concentration of $2.0 \mathrm{mg} \mathrm{L}^{-1}$ after 6 weeks of culture. After two subcultures the multiplication rate was increased up to 19 shoots per explant on medium with $2 \mathrm{iP}\left(1.0 \mathrm{mg} \mathrm{L}^{-1}\right)$. To prevent tissue browning, ascorbic acid and casein hydrolysate were added to the induction medium, resulting in a reduction of browning by $30 \%$. The rooted plantlets were successfully transferred to soil and acclimatized with $97 \%$ frequency. Quantitative and qualitative assessments of oenothein B and phenolic acid contents in in vitro regenerated shoots as well as in ex vitro plants were performed using high-performance liquid chromatography with a diode-array detector (HPLC-DAD) and ultra-performance liquid chromatography-tandem mass spectrometry (UPLC MS/MS) methods. Oenothein B (1.62-4.55 g $\left.100 \mathrm{~g}^{-1} \mathrm{DW}\right)$, ellagic acid, gallic and caffeic acids were identified in in vitro regenerated plants. The results of this study confirm that the oenothein B-producing plantlets can be obtained using the micropropagation method with axillary shoots being a valuable source of oenothein $\mathrm{B}$ and phenolic acids.
\end{abstract}

\section{Key message}

An efficient regeneration protocol from nodal explants of fireweed (Chamerion angustifolium (L.) Holub) was developed for the first time. The presence of oenothein B and phenolic acids in regenerated shoots and ex vitro cultivated plants was confirmed using HPLC-DAD and UPLC analysis.

Keywords Chamerion angustifolium (L.) Holub · Nodal explants · Shoot cultures · HPLC-DAD · UPLC MS/MS · Oenothein B

Communicated by Ali R. Alan.

Mariola Dreger

mariola.dreger@iwnirz.pl

1 Department of Biotechnology, Institute of Natural Fibres and Medicinal Plants, Wojska Polskiego 71B, 60-630 Poznań, Poland

2 Department of Pharmacology and Phytochemistry, Institute of Natural Fibres and Medicinal Plants, Kolejowa 2, 62-064 Plewiska, Poland

\section{Introduction}

Fireweed (Chamerion angustifolium (L.) Holub, Chamaenerion angustifolium (L.) Scop. syn. Epilobium angustifolium L.) is an herbaceous perennial plant from the Onagraceae family. The genus Chamerion is a separate monophyletic group with eight species restricted to the northern hemisphere (Wagner et al. 2007). Fireweed plants usually grow up to $2 \mathrm{~m}$ high and develop inflorescences with pink flowers from June to September. The species is widely distributed throughout the temperate zone of North America and Eurasia (Wagner et al. 2007). 
C. angustifolium has different ecological cytotypes: diploid $(2 \mathrm{n}=2 \times=36$ chromosomes), autotetraploid and also triploid and hexaploid (Husband and Schemske 1998, 2000; Guo et al. 2016). Cytotypes are associated with climatic and environmental factors such as adaptation to higher elevation (Martin and Husband 2013), microclimate conditions (Guo et al. 2016) or soil nitrogen supply (Bales and Hersch-Green 2019). Fireweed cytotypes have been used as a model system for studying cytotype polymorphism. Generally, diploid cytotype occurs at higher elevations and higher latitudes (Martin and Husband 2013), tetraploids are more common in the temperate zone (Husband and Schemske 1998; Thompson et al. 2014), whereas triploids appear in mixed-ploidy populations of border areas (Husband and Schemske 1998) and hexaploids are distributed in warmer climate zones (Guo et al. 2016).

Chamerion angustifolium it is known for its medicinal properties and it is utilized as a component of drugs, nutraceuticals and cosmetic products. Extracts obtained from the underground part are recommended in the treatment of benign prostatic hyperplasia (BPH) and prostatitis (EMEA 2015). Raw material (Epilobii herba) is a rich source of bioactive compounds: hydrolysable tannins, flavonoids, phenolic acids, sterols and others (Adamczak et al. 2019). Ellagitannins represent around $15 \%$ of the dry mass of the herb (Baert et al. 2015) and oenothein B is the most abundant ellagitannin, constituting 6 to $8 \%$ of the dried herb (Granica et al. 2012). Oenothein B is considered to be the main active compound, displaying anti-androgenic, antiproliferative, anticancer, antioxidant, anti-inflammatory, and immunomodulatory properties (Yoshida et al. 2018). Other characteristics of fireweed extracts are: also antimicrobial (Kosalec et al. 2013), analgesic (Tita et al. 2001), photoprotective and antiaging (Ruszova et al. 2013). Medicinal properties of $C$. angustifolium extracts have been attributed to the synergic effect of polyphenols. More than 50 flavonoids and their derivatives were identified in the fireweed herb (Adamczak et al. 2019). Quercetin-3-O-glucuronide is the characteristic flavonoid of fireweed, contrary to myricetin-3-Orhamnoside (myricitrin), which is the main flavonoid of the Epilobium species (Hevesi et al. 2009; Schepetkin et al. 2016). Phenolic acids and their derivatives are important contributors to the antioxidant and therapeutic potential against BPH of this species (Deng et al. 2019). Oenothein B, and quercetin-3-O-glucuronide levels are recommended as markers for raw material standardization (Kiss et al. 2011). C. angustifolium is a widely distributed plant but due to frequent interspecific hybridization is often misidentified and the marketed products are wrongly assigned (Kiss et al. 2011). Cultivation under controlled conditions can improve the yield of active compounds and production stability, providing high quality and homogeneous raw material. Conventional plant-breeding is based on cultivars which are well adapted to field conditions and mass production. However, development of suitable cultivars, characterized by high content of active compounds and stress tolerant, is a timeconsuming process, lasting even decades. Harvesting raw material from the natural habitat involves the problems with: variable content of active compounds, misidentification of botanical origin, toxins and contaminants etc. Moreover, it contributes to loss of genetic diversity and habitat destruction. Fireweed is a melliferous plant and plays an important role for insects, especially wild bees and others pollinators. Consumption of medicinal plants and demand for the raw material are still growing. For the sustainable use of medicinal plant resources biotechnological approaches including micropropagation and cultivation practice are recommended (Chen et al. 2016). In vitro cultures and micropropagation techniques offers the opportunity to significantly shorten the process of reproduction, and allow large scale multiplication of true-type plants to be achieved. Micropropagated plants can be used as the reproductive material to produce diseasefree clones without any seasonal variation and rich in bioactive compounds. There are only two reports on the in vitro cultures of C. angustifolium (Turker et al. 2008; Dreger et al. 2016). Both describe shoot regeneration from the seedling's root explants. Nevertheless, a reproducible regeneration protocol from the adult explants was missing. Such a protocol could be of potential use in germplasm conservation and for large scale multiplication of the selected high-yield genotypes of fireweed. The objective of the present study was to develop a regeneration protocol for nodal explants derived from shoots propagated in vitro and analyse the quantity and quality of phenolic compounds in plant material cultivated under in vitro and ex vitro conditions. The protocol allows for multiplication of oenothein B-producing plantlets and harvesting high-quality raw material. The results of this study are part of a project in which in vitro cultures and micropropagation technique were used for the first time in order to obtain fireweed raw material for the pilot production of a dietary supplement used in BPH prevention.

\section{Materials and methods}

\section{Source of plant material}

Chamerion angustifolium seeds, obtained from RiegerHofmann GmbH (Germany) and from the Garden of Medicinal Plants in Plewiska (Institute of Natural Fibres \& Medicinal Plants, INF\&MP Poland), were used for induction of in vitro cultures and micropropagation. Voucher specimens were identified by the authors, checked by Dr. Artur Adamczak (INF\&MP Poznań, Poland) and deposited in the INF\&MP. Seeds were surface-sterilized by soaking in $70 \%$ ethanol $(1 \mathrm{~min})$ and then in commercial bleach 
(ACE® solution 2:1) with a drop of Tween 20 (3-4 min), and afterwards washed three times in sterile water. Sterilized seeds were germinated on Petri dishes containing full strength MS basal medium (Murashige and Skoog 1962 ) with no plant growth regulators (PGRs). Shoot tips $(0.5 \mathrm{~cm})$ and nodal segments $(0.5-1.0 \mathrm{~cm})$ including $1-2$ axillary buds from the 7 -week old plants were used to initiate the cultures of shoot tips and nodal cuttings. Individual shoots cut for shoot tips and nodal segments were subcultured every 7 weeks on $1 / 2$ MS medium with half the macro- and micro- nutrients supplemented with $0.5 \mathrm{mg}$ $\mathrm{L}^{-1}$ of indole-3-acetic acid (IAA) and sucrose (3\%). Plant regeneration proceeded at $20^{\circ} \mathrm{C} \pm 2{ }^{\circ} \mathrm{C}$ with a $16 \mathrm{~h}$ photoperiod under a photosynthetic flux of $50-60 \mu \mathrm{mol} \mathrm{m} \mathrm{m}^{2} \mathrm{~s}^{-1}$ (daylight fluorescent tubes).

\section{Shoot induction, multiplication and elongation}

Nodal explants $(1.0 \mathrm{~cm})$ with two axillary buds were taken from shoots grown in vitro for 7 weeks (Fig. 1a). Individual explants were transferred to separate glass jars $(50 \mathrm{~mL})$ containing MS medium supplemented with $3 \%$ sucrose, vitamin $\mathrm{C}\left(0.1 \mathrm{~g} \mathrm{~L}^{-1}\right)$ and PGRs, namely 6-benzylaminopurine (BAP), 2-isopentenyladenine (2iP) and zeatin (Z) at concentrations: $0.1 \mathrm{mg} \mathrm{L}^{-1}, 0.5 \mathrm{mg} \mathrm{L}^{-1}, 1.0 \mathrm{mg} \mathrm{L}^{-1}$, $2.0 \mathrm{mg} \mathrm{L}^{-1}$ and $3.0 \mathrm{mg} \mathrm{L}^{-1}$. MS medium without PGRs was used as control. After 6 weeks, the following data were recorded: percentage of explants producing axillary shoots and buds, and their mean number per explant and percentage of callusing explants. In the separate experiment, the proliferated explants were subcultured twice on MS medium
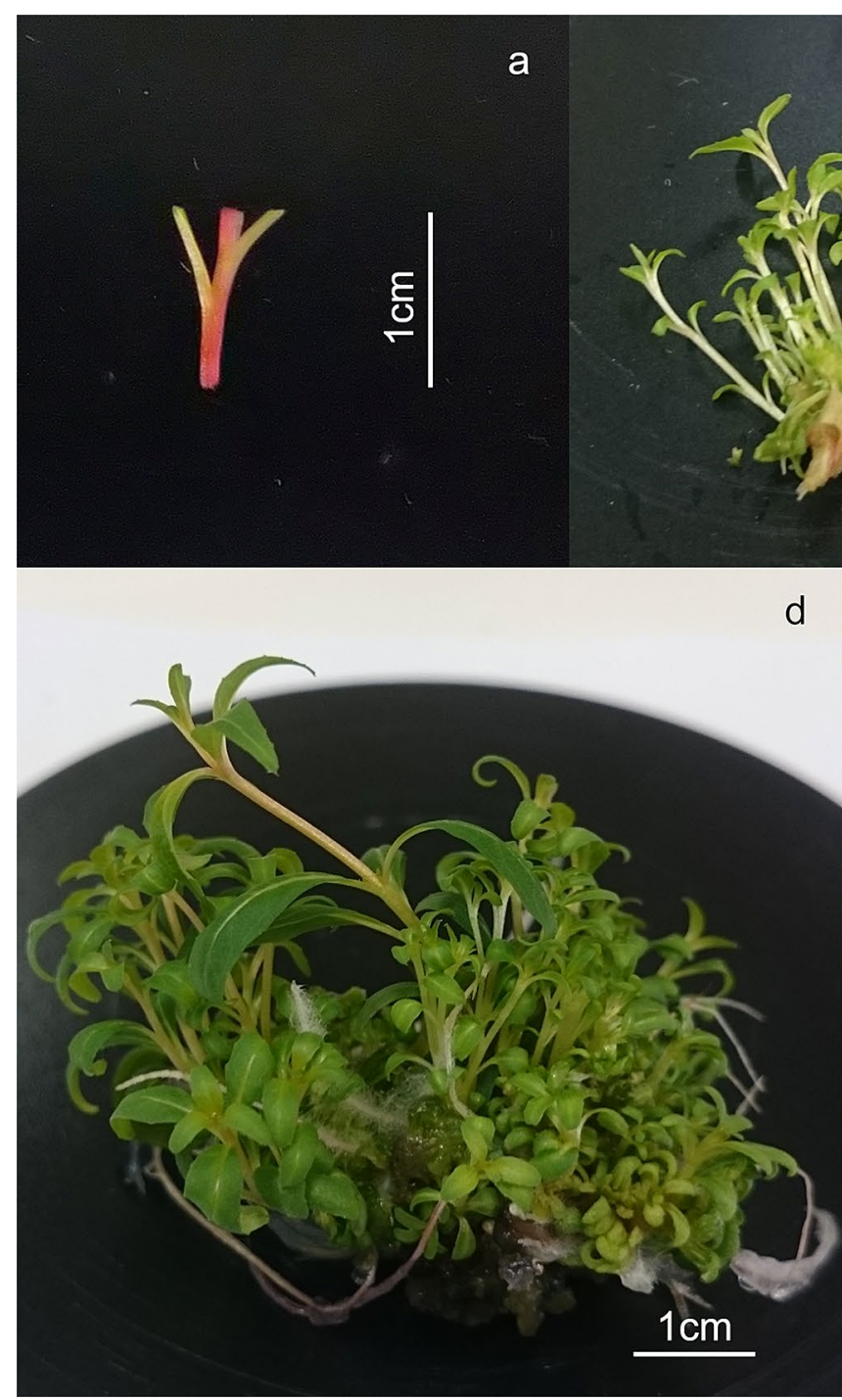

Fig. 1 C. angustifolium regeneration and multiplication a nodal explant, b shoots after 6 weeks of culture on MS medium with 2iP $\left(2.0 \mathrm{mg} \mathrm{L}^{-1}\right)$ and vitamin $\mathrm{C}\left(0.1 \mathrm{~g} \mathrm{~L}^{-1}\right)$, $\mathbf{c}$ browning multi-shoot on
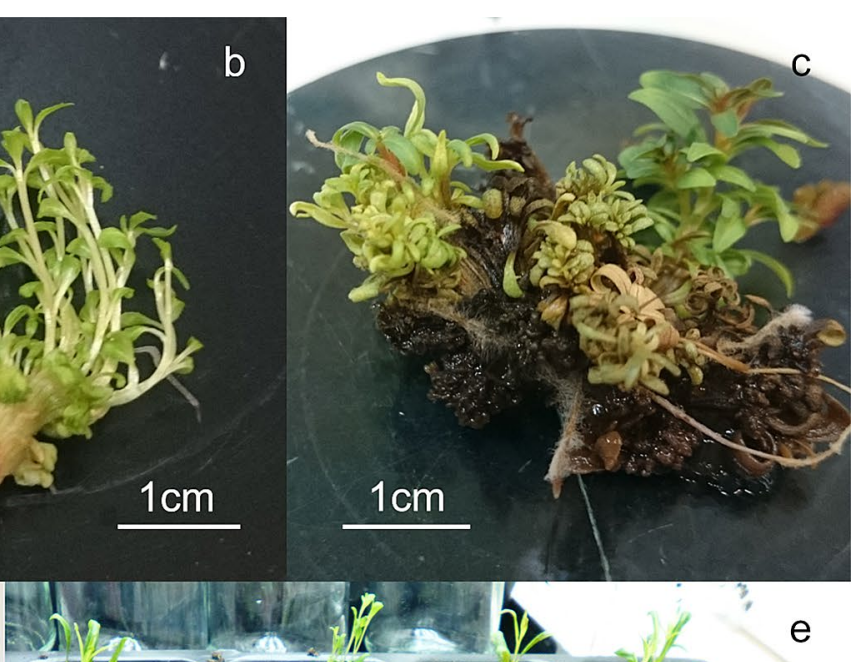

e

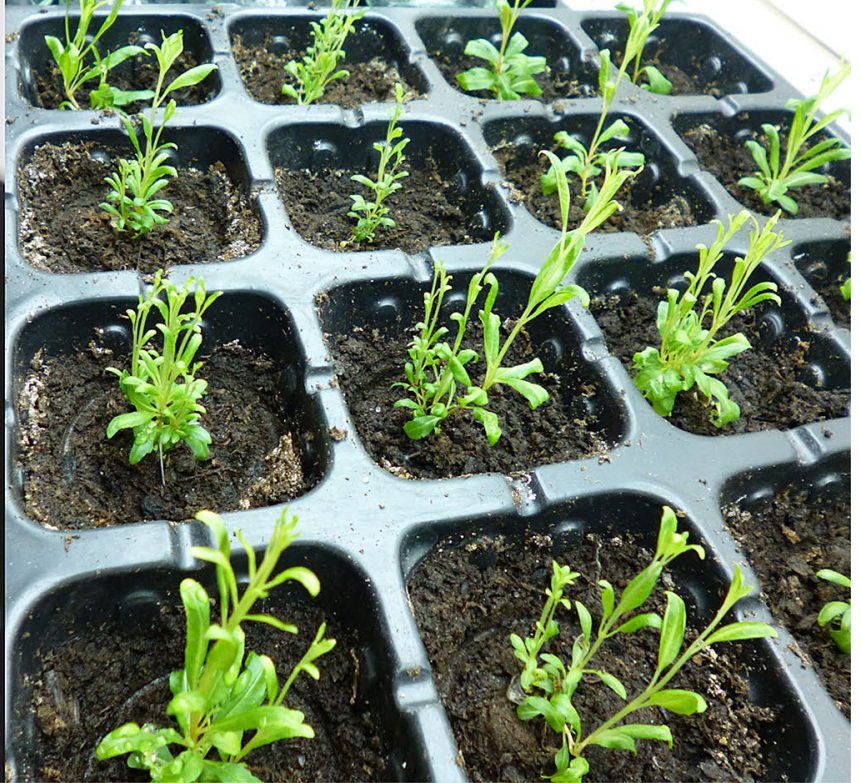

medium with zeatin $\left(3.0 \mathrm{mg} \mathrm{L}^{-1}\right)$ after second subculture, $\mathbf{d}$ shoot multiplication on MS medium with $2 \mathrm{iP}\left(2.0 \mathrm{mg} \mathrm{L}^{-1}\right)$ and vitamin $\mathrm{C}$ $\left(0.1 \mathrm{~g} \mathrm{~L}^{-1}\right)$, e acclimatization 
supplemented with $2 \mathrm{iP}\left(1.0\right.$ and $\left.2.0 \mathrm{mg} \mathrm{L}^{-1}\right)$ and zeatin (3.0 $\mathrm{mg} \mathrm{L}^{-1}$ ), and after 8 weeks transferred to elongation MS medium without PGRs. After 2 weeks, the number of shoots $(>0.5 \mathrm{~cm})$ and the mean number of shoots per explant were recorded and the length of shoots was measured. Multiplication of shoots was replicated three times for each treatment using at last 10 explants.

\section{Evaluation of anti-browning agents}

Ascorbic acid $\left(0.1 \mathrm{~g} \mathrm{~L}^{-1}\right)$, alone and combined with polyvinylpyrrolidone (PVP) at concentrations of $0.25 \mathrm{~g} \mathrm{~L}^{-1}$ and $0.5 \mathrm{~g} \mathrm{~L}^{-1}$ as well as with the same concentration of casein hydrolysate, was added to medium containing $2 \mathrm{iP}(1.0 \mathrm{mg}$ $\mathrm{L}^{-1}$ ) to test their effect on suppression of browning tissue. Medium with 2iP but without anti-browning agents was a control. The number of explants that became brown was counted after 4 weeks, and the percentage of browning explants was calculated for two subcultures. The experiment was replicated three times for each treatment using 15 explants.

\section{Rooting and acclimatization}

Shoots $(>1 \mathrm{~cm})$ were isolated from multi-shoots and transferred to half-strength MS medium ( $\left.1 \frac{1}{2} \mathrm{MS}\right)$ with ascorbic acid (control) and $1 / 2$ MS media supplemented with IAA and indole-3-butyric acid (IBA), both at concentration $0.5 \mathrm{mg}$ $\mathrm{L}^{-1}$. After 4 weeks, data were documented on percentage of rooting plants, number of roots per shoot and root length (cm). Each experiment was repeated three times with 24 shoots per treatment. Well-rooted 4-week-old plantlets were washed with sterile water to remove adherent medium from roots and planted in a plastic block tray $(5 \times 6)$ with autoclaved soil and perlite $(2: 1 \mathrm{v} / \mathrm{v})$ and covered with glass cups. After 2 weeks the cups were removed. The percentage of acclimatized plants was calculated after 4 weeks of acclimatization.

\section{Media and culture conditions}

All media contained sucrose (3\%), vitamin $\mathrm{C}\left(0.1 \mathrm{~g} \mathrm{~L}^{-1}\right)$ and were solidified with Bacto Agar $(0.8 \%)$. The $\mathrm{pH}$ was adjusted to 5.7 before autoclaving at $121{ }^{\circ} \mathrm{C}$ at $0.1 \mathrm{MPa}$ for 20 min. All chemicals were supplied by Sigma-Aldrich Ltd. Co. (St. Louis, US), except Bacto Agar (Becton, Dickinson and Company, USA) and vitamin C (POCH S.A., Poland). Plant regeneration, rooting and acclimatization proceeded at $25{ }^{\circ} \mathrm{C} \pm 2{ }^{\circ} \mathrm{C}$ and with a $16 \mathrm{~h}$ photoperiod under a photosynthetic flux of $60-80 \mu \mathrm{mol} \mathrm{m} \mathrm{s}^{-1}$ (daylight fluorescent tubes).

\section{Phytochemical analysis}

Five-week-old axillary shoots obtained on media supplemented with $2 \mathrm{iP}$ and zeatin (bulk sample) as well shoots harvested from the soil-grown plants were collected and dried at room temperature. Additionally, axillary shoots derived from different media were collected separately and subjected to the phytochemical analysis of phenolic compounds: oenothein B and phenolic acids (Table 6). Content of oenothein B was determined using HPLC-DAD method. Content of selected phenolic acids (ellagic, caffeic, gallic and rosmarinic acids) was determined using the UPLC method (Tables 5 and 6).

\section{HPLC-DAD analysis of oenothein B}

The method of extraction of oenothein B developed by Bazylko et al. (2007) was adapted to this research. Approximately $50 \mathrm{mg}$ of plant material was placed in a $50 \mathrm{~mL}$ volumetric flask, $35 \mathrm{~mL}$ of water was added to the sample and the mixture was extracted in an ultrasonic bath for $60 \mathrm{~min}$ at $40{ }^{\circ} \mathrm{C}$. The sample was cooled down and $5.0 \mathrm{~mL}$ of acetonitrile was added. Subsequently, the sample was filled up with water and the solution was passed through the $0.45 \mu \mathrm{m}$ filters. The oenothein B detection method was adapted to this study (Kiss et al. 2011). The LiChrospher $100 \mathrm{RP}-18 \mathrm{e}, 250 \mathrm{~mm} \times 4 \mathrm{~mm} \times 5 \mu \mathrm{m}$ (Merck, Germany) was used as a stationary phase. The mixture of 2 mobile phases eluted this compound: $2.5 \% \mathrm{CH}_{3} \mathrm{COOH}$ (phase A) and $2.5 \%$ $\mathrm{CH}_{3} \mathrm{COOH}$ : acetonitrile $(2: 8 \mathrm{~V} / \mathrm{V})$ (phase B). The separation was performed in the following conditions: $0 \mathrm{~min}-7 \%$ phase B, 30 min $-20 \%$ phase B, 60 min- $40 \%$ phase B. The column temperature was $25^{\circ} \mathrm{C}$, the flow rate was $1.0 \mathrm{~mL} /$ min and the detection was at $\lambda=263 \mathrm{~nm}$. The peaks were identified comparing the retention time and UV-VIS spectra with those of standard solution.

\section{UPLC-MS/MS analysis of phenolic acids}

The extraction method described by Gryszczyńska et al. (2018) was used for phenolic acids extraction. Approximately $0.1 \mathrm{~g}$ of herb was placed in a $10 \mathrm{~mL}$ volumetric flask, $9 \mathrm{~mL}$ of methanol was added to the sample and the solution was extracted in an ultrasonic bath for $30 \mathrm{~min}$. After cooling down, $100 \mu \mathrm{L}$ of an internal standard (quercetin$\mathrm{D} 3, \mathrm{c}=0.100 \mathrm{mg} \mathrm{mL}^{-1}$ ) was added to the sample and filled up with methanol to $10 \mathrm{~mL}$. The sample was filtered with $0.20 \mu \mathrm{m}$ filters and analysed with UPLC-MS/MS. A chromatographic analysis was obtained on an Acquity UPLC BEH C18 column, $50 \mathrm{~mm} \times 2.1 \mathrm{~mm} \times 1.7 \mu \mathrm{m}$ (Waters, USA). The mobile phases were as follows: acetonitrile:methanol 80:20 $(\mathrm{V} / \mathrm{V})$ (phase A), $0.1 \%(\mathrm{~V} / \mathrm{V})$ formic acid solution in water (phase B). The flow rate was $0.15 \mathrm{~mL} / \mathrm{min}$. The assay was 
performed in a gradient elution procedure: $0.0 \mathrm{~min}-95 \%$ of phase B, 1 min- $95 \%$ of phase B, $1.5 \mathrm{~min}-50 \%$ of phase B, $2.5 \mathrm{~min}-25 \%$ of phase $\mathrm{B}, 4 \mathrm{~min}-0 \%$ of phase $\mathrm{B}, 6 \mathrm{~min}-$ $0 \%$ of phase B, 9 min $-90 \%$ of phase B, $10 \mathrm{~min}-95 \%$ of phase $\mathrm{B}$. The column temperature was $25^{\circ} \mathrm{C}$; the ion source temperature was $100^{\circ} \mathrm{C}$; the desolvation temperature was $325{ }^{\circ} \mathrm{C}$. The sample injection had a volume $7 \mu \mathrm{L}$, and the desolvation gas flow rate was $500 \mathrm{l} \mathrm{h}^{-1}$. The analysis was performed in negative ion charge, using multiple reaction monitoring (MRM) for qualitative and quantitative analyses.

\section{Statistical analysis}

The data were statistically analysed using one-way analysis of variance (ANOVA) and the statistical significance was determined applying Duncan's POST-HOC test as well as Fisher's protected least significance differences (LSD) and Student's $t$ test ( $\mathrm{p}$ value of 0.05 ). All the statistical analysis was performed using STATISTICA 10 (StatSoft Inc., 2011).

\section{Results}

\section{Effect of cytokinins on shoot induction and multiplication}

For shoot induction BAP, 2iP and zeatin were used (Table 1). Explants cultured on control medium (MS without PGRs) did not show any bud proliferation. However, shoot bud induction was recorded in all tested treatments of $2 \mathrm{iP}$, zeatin and at a lower concentration of BAP $(0.1$ and $0.5 \mathrm{mg}$ $\mathrm{L}^{-1}$ ). $2 \mathrm{iP}$ was the most responsive in terms of promoting shoots per explant, with the maximum $(6.57 \pm 1.14)$ recorded at $2.0 \mathrm{mg} \mathrm{L}^{-1}$ of $2 \mathrm{iP}$ after 6 weeks of culture. However, the frequency of bud proliferation was lower (maximum 73\%) than that recorded for zeatin (93\%). An increasing concentration of $2 \mathrm{iP}$ in the media significantly stimulated the number of shoots per explant up to the optimal level of $2 \mathrm{iP}$, beyond which a decrease in growth parameters was noted. The shoots obtained on media with the tested $2 \mathrm{iP}$ concentration were vigorous and well developed and did not show any morphological aberrations or callus formation. Browning of explants was observed within 4 weeks of culture for BAP and zeatin treatments despite the addition of ascorbic acid $\left(0.1 \mathrm{~g} \mathrm{~L}^{-1}\right)$. Most explants put on media supplemented with BAP at the highest concentration $(>0.5 \mathrm{mg}$ $\mathrm{L}^{-1}$ ) completely died out. Less intense browning of explants was observed for zeatin treatment. However, increasing the zeatin concentration $\left(2.0\right.$ and $\left.3.0 \mathrm{mg} \mathrm{L}^{-1}\right)$ resulted in darkening of multi-shoots and occasional callus formation. For shoot multiplication and elongation, the proliferated explants were subcultured twice on the same induction medium with $2 \mathrm{iP}\left(1.0\right.$ and $\left.2.0 \mathrm{mg} \mathrm{L}^{-1}\right)$ and zeatin $\left(3.0 \mathrm{mg} \mathrm{L}^{-1}\right)$ in
Table 1 Effect of PGRs (BAP, 2iP and zeatin) on shoot proliferation and multiplication from nodal explants after 4 weeks of cultivation on MS medium supplemented with PGRs and ascorbic acid $\left(0.1 \mathrm{~g} \mathrm{~L}^{-1}\right)$

\begin{tabular}{|c|c|c|c|c|c|}
\hline \multicolumn{3}{|c|}{ PGR $\left(\mathrm{mg} \mathrm{L}^{-1}\right)$} & \multirow{2}{*}{$\begin{array}{l}\text { Response } \\
\text { rate }(\%)\end{array}$} & \multirow{2}{*}{$\begin{array}{l}\text { Mean no. of } \\
\text { shoots per } \\
\text { explant }\end{array}$} & \multirow{2}{*}{$\begin{array}{l}\text { Explant form- } \\
\text { ing callus }(\%)\end{array}$} \\
\hline BAP & $2 \mathrm{iP}$ & $\mathrm{Z}$ & & & \\
\hline 0.0 & & & 0.0 & $1.00 \pm 0.00^{\mathrm{ab}}$ & 0.00 \\
\hline 0.1 & & & 10.0 & $1.13 \pm 0.07^{\mathrm{ab}}$ & 0.00 \\
\hline 0.5 & & & 13.0 & $1.03 \pm 0.08^{\mathrm{ab}}$ & 0.00 \\
\hline 1.0 & & & 10.0 & $0.00 \pm 0.00^{\mathrm{a}}$ & 0.00 \\
\hline 2.0 & & & 0.0 & $0.00 \pm 0.00^{\mathrm{a}}$ & 0.00 \\
\hline \multirow[t]{11}{*}{3.0} & & & 0.0 & $0.00 \pm 0.00^{\mathrm{a}}$ & 0.00 \\
\hline & 0.1 & & 37.7 & $1.87 \pm 0.24^{\mathrm{bc}}$ & 0.00 \\
\hline & 0.5 & & 70.0 & $4.43 \pm 0.73^{\mathrm{de}}$ & 0.00 \\
\hline & 1.0 & & 70.0 & $6.37 \pm 0.82^{\mathrm{fg}}$ & 0.00 \\
\hline & 2.0 & & 73.0 & $6.57 \pm 1.14^{\mathrm{g}}$ & 3.33 \\
\hline & 3.0 & & 66.7 & $4.07 \pm 1.02^{\mathrm{de}}$ & 3.33 \\
\hline & & 0.1 & 46.7 & $1.43 \pm 0.10^{\mathrm{abc}}$ & 0.00 \\
\hline & & 0.5 & 80.0 & $1.80 \pm 0.41^{\mathrm{bc}}$ & 0.00 \\
\hline & & 1.0 & 83.0 & $1.87 \pm 0.53^{\mathrm{bc}}$ & 0.00 \\
\hline & & 2.0 & 93.0 & $3.00 \pm 0.51^{\mathrm{cd}}$ & 0.00 \\
\hline & & 3.0 & 90.0 & $5.07 \pm 0.97^{\mathrm{ef}}$ & 3.33 \\
\hline
\end{tabular}

Values are mean \pm standard error of 10 replicates per treatment in three repeated experiments. Mean values with column with the same letter are not significantly different at $\mathrm{p}=0.05$ (Duncan's multiple range test)

Table 2 Effect of $2 \mathrm{iP}$ and zeatin on shoot multiplication after 2 subcultures (10 weeks of culture)

\begin{tabular}{|c|c|c|c|c|}
\hline \multicolumn{2}{|c|}{$\begin{array}{l}\text { PGR (mg } \\
\left.\mathrm{L}^{-1}\right)\end{array}$} & \multirow{2}{*}{$\begin{array}{l}\text { Mean no. of } \\
\text { shoots per } \\
\text { explant }\end{array}$} & \multirow[t]{2}{*}{ Shoot length $(\mathrm{cm})$} & \multirow{2}{*}{$\begin{array}{l}\text { Percent of mal- } \\
\text { formed or hyper- } \\
\text { hydrous shoots }\end{array}$} \\
\hline $2 \mathrm{iP}$ & Zeatin & & & \\
\hline 1.0 & & $19.52 \pm 3.33^{\mathrm{a}}$ & $2.03 \pm 0.26^{\mathrm{a}}$ & 0.0 \\
\hline \multirow[t]{2}{*}{2.0} & & $15.46 \pm 2.14^{\mathrm{b}}$ & $1.04 \pm 0.14^{\mathrm{b}}$ & 6.0 \\
\hline & 3.0 & $2.86 \pm 1.47^{\mathrm{c}}$ & $0.90 \pm 0.60^{c}$ & 3.0 \\
\hline
\end{tabular}

Values are mean \pm standard error of 10 replicates per treatment in three repeated experiments. Mean values in a column with the same letter are not significantly different at $\mathrm{p}=0.05$ (Duncan's multiple range test)

two subcultures in 4-week intervals, and then were transferred to elongation MS medium without PGRs (2 weeks). A significant increase of shoot number per explant, up to 15.5 and 19.5 was noted on the medium with 2iP (Table 2; Fig. 1d). Shoot growth was also superior for $2 \mathrm{iP}$ treatment and the average length of shoots was $2.03( \pm 0.26) \mathrm{cm}$ and $1.04( \pm 0.14) \mathrm{cm}$, corresponding inversely proportionally to $2 \mathrm{iP}$ concentration. The explants exposed to repeated zeatin treatment became browned and up to $45 \%$ died. In addition, unfavourable effects such as hyperhydricity and malformation were noted. 
Table 3 Effect of combination of anti-browning agents on reducing browning on induction medium with $2 \mathrm{iP}\left(1.0 \mathrm{mgL}^{-1}\right)$ and different additives in two subcultures

\begin{tabular}{|c|c|c|c|c|}
\hline \multicolumn{3}{|c|}{ Anti-browning agent $\left(\mathrm{g} \mathrm{L}^{-1}\right)$} & \multirow{2}{*}{$\begin{array}{l}\text { Subculture } 1 \\
\text { Percentage of } \\
\text { explants (\%) }\end{array}$} & \multirow{2}{*}{$\begin{array}{l}\text { Subculture } 2 \\
\text { rowning }\end{array}$} \\
\hline Ascorbic acid & $\begin{array}{l}\text { Casein } \\
\text { hydrolysate }\end{array}$ & PVP & & \\
\hline 0.0 & & & $71.88^{\mathrm{a}}$ & $100.00^{\mathrm{a}}$ \\
\hline 0.1 & & & $61.29^{\mathrm{ab}}$ & $77.42^{\mathrm{c}}$ \\
\hline 0.1 & 0.25 & & $43.33^{\mathrm{b}}$ & $83.33^{\mathrm{bc}}$ \\
\hline 0.1 & 0.5 & & $64.56^{\mathrm{ab}}$ & $90.32^{\mathrm{abc}}$ \\
\hline 0.1 & & 0.25 & $44.45^{\mathrm{b}}$ & $96.97^{\mathrm{ab}}$ \\
\hline 0.1 & & 0.5 & $44.45^{\mathrm{b}}$ & $81.81^{\mathrm{bc}}$ \\
\hline
\end{tabular}

Values are the percentage of 15 replicates in three repeated experiments. Mean values in a column with the same letter are not significantly different at $\mathrm{p}=0.05$ (Fisher's test)

\section{Effect of adsorbent and antioxidant combination on tissue browning}

To prevent browning of explants the combination of ascorbic acid $\left(0.1 \mathrm{~g} \mathrm{~L}^{-1}\right)$ with casein hydrolysate and PVP both at concentration 0.25 and $0.5 \mathrm{~g} \mathrm{~L}^{-1}$ were tested in a separate experiment including two subcultures (Table 3). After first subculture the most effective inhibition of browning was recorded for the combination of vitamin $\mathrm{C}$ with casein hydrolysate $\left(0.25 \mathrm{~g} \mathrm{~L}^{-1}\right)$ and PVP. Less than $50 \%$ of explants put on these media showed tissue browning after 4 weeks of culture. Addition of casein hydrolysate, but only at lower concentration $\left(0.25 \mathrm{~g} \mathrm{~L}^{-1}\right)$ led to the most effective reduction of browning (43.3\%), but similar results (44.5\%) were achieved for the combination of vitamin $\mathrm{C}$ with PVP irrespective of its concentration. The browning rate recorded for control medium (without any anti-browning agent) was $72 \%$ and for medium with vitamin C was only slightly lower (61\%). After the second subculture, the significant majority of explants showed browning of tissue (100-77\%) irrespectively of the treatment.

\section{Rooting and acclimatization}

The separated shoots $(>1 \mathrm{~cm})$ derived from multi-shoots were rooted on media with IAA and IBA (Table 4). The shoots rooted easily within 4 weeks even on a control medium without added auxins. The highest rooting, up to $98.6 \%$, was noted for medium enriched with IBA. However, the rooting rates for all treatments were in a similar range ( $97 \%$ vs. $96 \%$ vs. $99 \%$ ). The number of roots per shoot was similar for auxin treatments (9.9 and 9.65 per shoot) and was significantly higher than that observed for the control medium (5.24). Shoots cultured in media with auxins produced almost two-fold more roots than in the control medium, but the root length was shorter $(6.63 \mathrm{~cm}$ vs. $4.58 \mathrm{~cm}$ vs. $5.35 \mathrm{~cm})$. Plantlets, after transplanting
Table 4 Effect of auxin (IAA/IBA) on root induction after 4 weeks of culture on rooting medium

\begin{tabular}{llll}
\hline Auxin $\left(\mathrm{mg} \mathrm{L}^{-1}\right)$ & $\begin{array}{l}\text { \% of rooted } \\
\text { shoots }\end{array}$ & $\begin{array}{l}\text { Mean no. } \\
\text { of root per } \\
\text { shoot }\end{array}$ & $\begin{array}{l}\text { Mean root length } \\
(\mathrm{cm})\end{array}$ \\
\hline 0.0 & $97.20^{\mathrm{a}}$ & $5.24 \pm 0.24^{\mathrm{a}}$ & $6.63 \pm 0.27^{\mathrm{a}}$ \\
IAA $(0.5)$ & $95.80^{\mathrm{a}}$ & $9.90 \pm 0.48^{\mathrm{b}}$ & $4.58 \pm 0.20^{\mathrm{b}}$ \\
IBA $(0.5)$ & $98.60^{\mathrm{a}}$ & $9.65 \pm 0.40^{\mathrm{b}}$ & $5.35 \pm 0.20^{\mathrm{c}}$ \\
\hline
\end{tabular}

Values are mean \pm standard error of 25 replicates per treatment in three repeated experiments. Mean values in a column with the same letter are not significantly different at $\mathrm{p}=0.05$ (Fisher's test (\%) and Duncan's multiple range test)

into soil, grew vigorously (Fig. 1e) and $96.7 \%$ of them successfully survived the hardening process.

\section{Phytochemical analysis}

The harvested shoots from in vitro culture as well as the soil-grown plants were subjected to phytochemical analysis by the HPLC-DAD and UPLC MS/MS methods (Tables 5 and 6). Relatively high contents of oenothein B (1.62-4.55 g $\left.100 \mathrm{~g}^{-1} \mathrm{DW}\right)$ and ellagic acid (85.50-222.41 mg $100 \mathrm{~g}^{-1}$ DW) were determined. No flavonoids were found in the tested material. The highest content of oenothein B ( $4.55 \mathrm{mg} 100 \mathrm{~g}^{-1} \mathrm{DW}$ ) was found in the acclimatized plantlets (Table 5). Content of oenothein B varied in shoot cul-

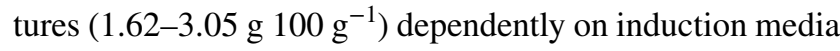
(Table 6). The highest concentration of this compound was determined in shoots cultivated in medium with $2 \mathrm{iP}$ $\left(0.5 \mathrm{mg} \mathrm{L}^{-1}\right)$. Among phenolic acids, ellagic acid was the most abundant, especially in axillary shoots (Table 6). The presence of small amounts of gallic acid (2.79-11.34 mg $\left.100 \mathrm{~g}^{-1} \mathrm{DW}\right)$, caffeic acid (1.19-4.76 mg $\left.100 \mathrm{~g}^{-1} \mathrm{DW}\right)$

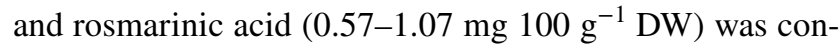
firmed in all samples. The contents of phenolic acids varied depending on the induction media. The highest content of ellagic acid (221.30-222.41 mg $\left.100 \mathrm{~g}^{-1} \mathrm{DW}\right)$, gallic acid (11.34-11.23 mg $\left.100 \mathrm{~g}^{-1} \mathrm{DW}\right)$ as well rosmarinic acid (1.07-0.97 mg $100 \mathrm{~g}^{-1} \mathrm{DW}$ ) was determined in the shoots cultivated in media at lower concentration of $2 \mathrm{iP}(0.5$ and $\left.1.0 \mathrm{mg} \mathrm{L}^{-1}\right)$. Shoots cultivated on medium with zeatin $\left(2.0 \mathrm{mg} \mathrm{L}^{-1}\right)$ or higher $2 \mathrm{iP}$ concentration $\left(2.0 \mathrm{mg} \mathrm{L}^{-1}\right)$ accumulated a significantly lower level of ellagic acid as well as gallic and rosmarinic acids.

\section{Discussion}

To our best knowledge, there are only two reports concerning in vitro culture of Chamerion angustifolium (L.) Holub (Turker et al. 2008; Dreger et al. 2016). Both reports 
Table 5 Content of oenothein $\mathrm{B}$ and phenolic acids in $C$. angustifolium shoot cultures cultivated on different induction media (bulk sample) and in the acclimatized plantlets

\begin{tabular}{llllll}
\hline Sample & Oenothein B g & \multicolumn{2}{l}{$\mathrm{mg} 100 \mathrm{~g}^{-1} \mathrm{DW}$} & \\
\cline { 2 - 5 } & $100 \mathrm{~g}^{-1} \mathrm{DW}$ & Caffeic acid & Gallic acid & Ellagic acid & Rosmarinic acid \\
\hline Shoot culture & $2.46 \pm 0.08^{\mathrm{a}}$ & $1.53 \pm 0.02^{\mathrm{a}}$ & $4.17 \pm 0.06^{\mathrm{a}}$ & $88.02 \pm 0.58^{\mathrm{a}}$ & $0.63 \pm 0.02^{\mathrm{a}}$ \\
Plantlets & $4.55 \pm 0.05^{\mathrm{b}}$ & $1.19 \pm 0.02^{\mathrm{b}}$ & $2.79 \pm 0.07^{\mathrm{b}}$ & $85.50 \pm 0.28^{\mathrm{a}}$ & $0.77 \pm 0.02^{\mathrm{b}}$ \\
\hline
\end{tabular}

Values are mean \pm standard deviation of two replicates. Mean values in a column with the same letter are not significantly different at $\mathrm{p}=0.05$ (Student's t-test)

\begin{tabular}{|c|c|c|c|c|c|}
\hline \multirow[t]{2}{*}{ Induction medium } & \multirow{2}{*}{$\begin{array}{l}\text { Oenothein B g } \\
100 \mathrm{~g}^{-1} \text { DW }\end{array}$} & \multicolumn{4}{|c|}{$\mathrm{mg} 100 \mathrm{~g}^{-1} \mathrm{DW}$} \\
\hline & & Caffeic acid & Gallic acid & Ellagic acid & Rosmarinic acid \\
\hline $\mathrm{MS}+\mathrm{Z}\left(3.0 \mathrm{mg} \mathrm{L}^{-1}\right)$ & $2.31 \pm 0.10^{\mathrm{a}}$ & $3.02 \pm 0.48^{\mathrm{a}}$ & $3.55 \pm 0.57^{\mathrm{a}}$ & $97.59 \pm 14.21^{\mathrm{a}}$ & $0.57 \pm 0.00^{\mathrm{a}}$ \\
\hline $\mathrm{MS}+2 \mathrm{iP}\left(0.5 \mathrm{mg} \mathrm{L}^{-1}\right)$ & $3.05 \pm 0.09^{b}$ & $4.59 \pm 0.02^{\mathrm{b}}$ & $11.34 \pm 0.53^{\mathrm{b}}$ & $222.41 \pm 5.24^{\mathrm{b}}$ & $1.07 \pm 0.04^{\mathrm{b}}$ \\
\hline $\mathrm{MS}+2 \mathrm{iP}\left(1.0 \mathrm{mg} \mathrm{L}^{-1}\right)$ & $1.62 \pm 0.03^{c}$ & $4.76 \pm 0.04^{\mathrm{b}}$ & $11.23 \pm 0.14^{\mathrm{b}}$ & $221.30 \pm 1.08^{\mathrm{b}}$ & $0.97 \pm 0.04^{b}$ \\
\hline $\mathrm{MS}+2 \mathrm{iP}\left(2.0 \mathrm{mg} \mathrm{L}^{-1}\right)$ & $2.72 \pm 0.11^{\mathrm{d}}$ & $2.78 \pm 0.00^{\mathrm{a}}$ & $7.35 \pm 0.13^{\mathrm{c}}$ & $145.70 \pm 0.40^{\mathrm{c}}$ & $0.60 \pm 0.03^{\mathrm{c}}$ \\
\hline
\end{tabular}

Values are mean \pm standard deviation of two replicates. Mean values in a column with the same letter are not significantly different at $\mathrm{p}=0.05$ (Duncan's test)
Table 6 Content of oenothein $\mathrm{B}$ and phenolic acids in axillary shoots of $C$. angustifolium cultivated on different induction media for 5 weeks browning of explants and necrosis up to $50 \%$. Necrosis of explants occurred in response to $\mathrm{BAP}$, whereas $2 \mathrm{iP}$ was reported to have a favorable effect on shoot induction in some Rhododendron species (Norton and Norton 1985) and Genista sp. cultivars (Łuczkiewicz and Piotrowski 2005). Differences in the activity of cytokinins may result from their affinity to cytokinin oxidase/dehydrogenase enzymes (CKX). It has been documented that CKX enzymes are involved in one of the key mechanisms in the control of the cytokinin content in plants (Werner et al. 2006; Niemann et al. 2018). Because CKX recognizes the double bond of the isoprenoid side chain, it is highly specific for isoprenoid cytokinins, e.g. trans-zeatin and 2iP. BAP is an aromatic cytokinin and it is practically resistant to CKX enzymes. Individual CKX isoforms are expressed in different tissues and differ partially in their substrate specificities (Werner et al. 2006). Different affinity to CKX enzymes did not explain browning of explants and necrosis. However, it has been suggested that cytokinin degradation by CKXs in the apoplast might be functionally linked to quinones (Galuszka et al. 2005), which are highly reactive and might lead to lethal browning of explants (Murata et al. 2002; Ko et al. 2009). Moreover, a high concentration of BAP is able to induce programmed cell death in plant cultured cells (Kunikowska et al. 2013).

This study also documents that the key obstacle for in vitro culture of $C$. angustifolium is the browning of explants. This physiological reaction is often a challenge for successful establishing of in vitro cultures, especially in the case of phenolic-abundant species. Tissue browning in C. angustifolium cultures was also reported by Turker et al. (2008) and Dreger et al. (2016). In our previous study, about $20 \%$ of shoot tips died due to tissue browning or necrosis 
(Dreger et al. 2016). In general, tissue browning is a result of polyphenols' oxidation by different oxidase enzymes (peroxidase, polyphenol oxidase, and L-phenylalanine ammonialyase) (Xu et al. 2007; Leng et al. 2009). When tissues are wounded, which is inevitable during cutting or subculture of explants, enzymes and polyphenol substrates $(O$-hydroxypolyphenols, tyrosine etc.) are released and quinones are produced as a result of polyphenols' oxidation (Murata et al. 2002; Leng et al. 2009). Further, polymerization of quinones is manifested by brown or black pigment (Murata et al. 2002). Tissue browning might lead to necrosis of explants; therefore different antioxidants such as ascorbic acid (Turker et al. 2008) or adsorbents such as PVP or activated carbon (Li et al. 2015) are added to the media, to prevent browning. In this study ascorbic acid $\left(0.1 \mathrm{~g} \mathrm{~L}^{-1}\right)$ was added to all media, but the effect was not satisfactory. In the first experiment, most of the formed multi-shoots showed browning of tissue with varying degrees of severity (Fig. 1c). Ascorbic acid is light- and thermo-labile, so its efficacy is limited, particularly in prolonged culture. Therefore, combinations of vitamin C with PVP and with casein hydrolysate were tested in a separate experiments including two subcultures (Table 3). Testing showed that the combination of vitamin $\mathrm{C}$ with casein hydrolysate $\left(0.25 \mathrm{~g} \mathrm{~L}^{-1}\right)$ as well as with PVP significantly limited browning of explants, contrary to control medium and medium supplemented only with ascorbic acid. Less than $50 \%$ of explants put on these media showed tissue browning after the first subculture. Addition of casein hydrolysate, but only at lower concentration $\left(0.25 \mathrm{~g} \mathrm{~L}^{-1}\right)$ led to the most effective reduction of browning (browning rate 43\%), but similar results (45\%) were achieved for the combination of vitamin C with PVP irrespective its concentration. Casein hydrolysate is a mixture of peptides and amino acids with antioxidant activity and nutrient value (Irshad et al. 2015). It is a source of amino nitrogen and free amino acids, which differ in composition and exert variable influence on in vitro growth and morphogenesis (Baskaran and Jayabalan 2007; Al-Khayri 2011). The combination of ascorbic acid and casein hydrolysate might have resulted in a synergistic effect of antioxidant activity, which was shown as the reduction of browning. These results agree with the findings obtained by Bzducha and Wołosiak (2006), who documented the efficacy of the synergic effect of vitamin $\mathrm{C}$ and casein hydrolysate in a linoleic acid model oxidation system obtaining. The synergic effect was observed only for the lower concentration of casein hydrolysate $\left(0.25 \mathrm{~g} \mathrm{~L}^{-1}\right)$, which may mean that the combination of the components works within a certain concentration range and should be adjusted. Combination of vitamin C with PVP was comparably effective in inhibition of browning tissue. PVP is commonly used to reduce injury and tissue browning in in vitro cultures (Figueiredo et al. 2001; Li et al. 2015). It prevents oxidative browning of wound-induced polyphenolics via a hydrogen bonding mechanism (Tang et al. 2004). However, the anti-browning effect was time-limited and after the second subculture most of the multi-shoots (100-77\%) showed browning irrespectively of the treatment. Therefore, shortening of culture time to 3 weeks and earlier transfer of multi-shoots to elongation medium should be worth considering and recommending.

Rooting and hardening of plantlets are often critical stages for the micropropagation, but $C$. angustifolium plantlets were easily rooted (95.8-98.6\%) even on the control medium without auxins (Table 4 ). The optimal rooting rate (98.6\%) and others parameters like number of roots per shoot were achieved for the variant with IBA, although the differences between auxins and control were statistically insignificant. These findings are inconsistent with results obtained by Turker et al. (2008), who recorded the best rooting rate and number of roots for medium (MSMO) with IAA $\left(0.5 \mathrm{mg} \mathrm{L}^{-1}\right)$. On the other hand, Deliu et al. (2013) obtained the optimum rooting efficiency for medium without auxins but supplemented with activated charcoal. Alosaimi et al. (2018) also noted easy rooting of Epilobium canum garretti shoots on medium without added auxin. The noted differences may result from different plant material originating from different populations derived from different climatic zones. Therefore, further research on various plant material (different genotypes/populations) and the effects of different auxins on shoot rooting is worth considering. Plantlets, after transplanting into soil, grew vigorously and $96.7 \%$ of them successfully survived the hardening process. Similarly high survival rates of $98 \%$ and $95 \%$ of the acclimatized plants were obtained previously by Dreger et al. (2016) and Turker et al. (2008) respectively.

Quantitative analysis of oenothein B, caffeic, gallic and rosmarinic acids in axillary shoots as well in the shoots from the soil-harvested plants were performed by applying HPLC-DAD and UPLC MS/MS (Tables 5 and 6). Relatively

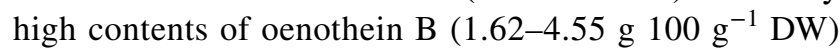
were confirmed in all samples. The content of oenothein $B$ in axillary shoots was comparable with field-cultivated plants (Gryszczyńska et al. 2018). Content of oenothein B

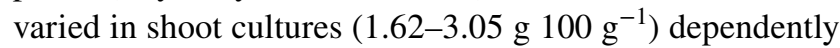
on induction media (Table 6). However, the highest content of oenothein B $\left(4.55 \mathrm{mg} 100 \mathrm{~g} \mathrm{~g}^{-1}\right)$ was found in the acclimatized plantlets (Table 5). Production of oenothein B and other ellagitannins (tellimagrandin I and II) and galloylglucoses in $O$. tetraptera shoot cultures was reported by Taniguchi et al. (2002). Changes in composition and content of ellagitannins was reported in shoots during regeneration and acclimatization. In vitro regenerated plants contained nearly two-fold higher concentration of oenothein B than seedlings or plantlets. The authors suggested a correlation between tannin accumulation with the leaves' development as an adaptation to UV light exposure (Taniguchi et al. 2002). Changes in the ellagitannin level are mainly related to their 
distribution in plant organ (Baert et al. 2017), plant stage (Jürgenson et al. 2012) or population origin (Baert et al. 2017). On the other hand, ellagitannins play a defensive role in plants against herbivores (Moilanen and Salminen 2008; Moilanen et al. 2016). Antiherbivore (Anstett et al. 2019) and antimicrobial (Hatano et al. 2005) properties of oenothein B have been documented. Therefore, increasing accumulation of oenothein B in plants may be influenced by environmental factors such as stress conditions during ex vitro hardening. Further studies are needed to determine the factors and their role in ellagitannin biosynthesis and their influence on the content of ellagitannins in plants.

Fireweed plants synthesise nearly 50 different flavonoids and their derivatives (Adamczak et al. 2019), but the presence of flavonoids was not detected in shoot cultures or the plantlets. The absence of flavonoids in shoot cultures of the related species-E. parviflorum and E. hirsutum-was reported earlier (Deliu et al. 2013). Presence and abundance of flavonoids in this species are mainly correlated with the blooming phase (Jürgenson et al. 2012; Baert et al. 2017). Therefore, the reason for the lack of flavonoids may be that the development phase of the tested plant material was too early.

Phenolic acids and their derivatives are one of the dominant groups of phenolics found in C. angustifolium plants, and are important contributors to the antioxidant and therapeutic potential of this species (Deng et al. 2019). In this study, relatively high contents of ellagic acid (85.50-222.41 mg $100 \mathrm{~g}^{-1} \mathrm{DW}$ ) were determined (Table 6). The presence of small amounts of gallic acid (2.79-11.34 mg $\left.100 \mathrm{~g}^{-1}\right)$, caffeic acid (1.19-4.76 mg $\left.100 \mathrm{~g}^{-1} \mathrm{DW}\right)$ and rosmarinic acid (0.53-1.07 mg $\left.100 \mathrm{~g}^{-1} \mathrm{DW}\right)$ was confirmed in all samples. Among phenolic acids, ellagic acid was the most abundant, especially in axillary shoots. The contents of gallic acid and ellagic acids were variable dependently on induction media. The highest content of ellagic acid (221.30-222.41 mg 100 g $\mathrm{g}^{-1} \mathrm{DW}$ ) was determined in shoots cultivated on media with lower concentration of $2 \mathrm{iP}(0.5$ and $\left.1.0 \mathrm{mg} \mathrm{L}^{-1}\right)$. Shoots cultivated on medium with zeatin $\left(2.0 \mathrm{mg} \mathrm{L}^{-1}\right)$ or higher $2 \mathrm{iP}$ concentration $\left(2.0 \mathrm{mg} \mathrm{L}^{-1}\right)$ accumulated a significantly lower level of ellagic acid as well as gallic and rosmarinic acids. The effect of PGRs in culture media on the accumulation of different groups of secondary metabolites is well documented. Variable content of phenolic acids depending on a medium hormonal variant was recorded in different species, e.g.: Ocimum americanum (Rady and Naagla 2005), Aronia melanocarpa (Szopa and Ekiert 2014) or Eryngium alpinum (Kikowska et al. 2019). This is the first report on the quantitative analysis of oenothein B and phenolic acids in shoot cultures of $C$. angustifolium. Based on the results of this study, it may be concluded that the developed micropropagation protocol allows one to obtain oenothein B-producing plantlets and harvest high-quality raw material.

\section{Conclusions}

In this study, a micropropagation protocol from nodal explants of $C$. angustifolium was developed and analysis of oenothein $\mathrm{B}$ and selected phenolic acids in shoot cultures was performed for the first time. This method is efficient since multiplication occurred within 6 weeks, producing more than 6 axillary shoots per explant or more than 19 shoots per explant within 10 weeks. The developed protocol may be used in mass propagation of the selected high-yield genotypes of fireweed, with axillary shoots being a valuable source of oenothein B and phenolic acids.

Acknowledgements The authors would like to express their thanks to Dr. Artur Adamczak for identification of the species and to Professor of Institute of Natural Fibres and Medicinal Plants Waldemar Buchwald for providing Chamerion angustifolium seeds from the collection of the Garden of Medicinal Plants in Plewiska.

Author contributions All authors contributed to the study concept and design. Material preparation and analysis were performed by MD and AG. Statistical analysis was performed by MS. The first draft of the manuscript was written by MD with a critical input from all authors. The draft of the manuscript was reviewed and edited by KW. All authors read and approved the final manuscript.

Funding This work was funded by the Polish National Centre of Research and Development (Grant No. PBS2/A8/23/2013).

\section{Compliance with ethical standards}

Conflict of interest The authors declare that they had no conflict of interest.

Open Access This article is licensed under a Creative Commons Attribution 4.0 International License, which permits use, sharing, adaptation, distribution and reproduction in any medium or format, as long as you give appropriate credit to the original author(s) and the source, provide a link to the Creative Commons licence, and indicate if changes were made. The images or other third party material in this article are included in the article's Creative Commons licence, unless indicated otherwise in a credit line to the material. If material is not included in the article's Creative Commons licence and your intended use is not permitted by statutory regulation or exceeds the permitted use, you will need to obtain permission directly from the copyright holder. To view a copy of this licence, visit http://creativecommons.org/licenses/by/4.0/.

\section{References}

Adamczak A, Dreger M, Seidler-Łożykowska K, Wielgus K (2019) Fireweed (Epilobium angustifolium L.): botany, phytochemistry and traditional uses. A review. Herba Pol 65:51-63. DOI:https:// doi.org/10.2478/hepo-2019-0018 
Al-Khayri JM (2011) Influence of yeast extract and casein hydrolysate on callus multiplication and somatic embryogenesis of date palm (Phoenix dactylifera L.). Sci Hortic 130:531-535. https://doi. org/10.1016/j.scienta.2011.07.024

Alosaimi A, Tripepi R, Love S (2018) Micropropagation of Epilobium canum garretti (Firechalice) by axillary shoot culture. Hort Sci 53:62-66. https://doi.org/10.21273/HORTSCI12396-17

Anstett DN, Cheval I, D'Souza C, Salminen j, Johnson MTJ (2019) Ellagitannins from the Onagraceae decrease the performance of generalist and specialist herbivores. J Chem Ecol 45:86-94. https ://doi.org/10.1007/s10886-018-1038-x

Baert N, Karonen M, Salminen JP (2015) Isolation, characterisation and quantification of the main oligomeric macrocyclic ellagitannins in Epilobium angustifolium by ultra-high performance chromatography with diode array detection and electrospray tandem mass spectrometry. J Chromatogr A 1419:26-36. https://doi. org/10.1016/j.chroma.2015.09.050

Baert N, Kim J, Karonen M, Salminen JP (2017) Inter-population and inter-organ distribution of the main polyphenolic compounds of Epilobium angustifolium. Phytochemistry 134:54-63. https://doi. org/10.1016/j.phytochem.2016.11.003

Bales AL, Hersch-Green EI (2019) Effects of soil nitrogen on diploid advantage in fireweed, Chamerion angustifolium (Onagraceae). Ecol Evol 9:1095-1109. https://doi.org/10.1002/ece3.4797

Baskaran P, Jayabalan (2007) Rapid micropropagation of Psoralea corylifolia $\mathrm{L}$. using nodal explants cultured in organic additivesupplemented medium. J Hortic Sci Biotechnol 82:908-913. https ://doi.org/10.1080/14620316.2007.11512325

Bazylko A, Kiss AK, Kowalski J (2007) High-performance thinlayer chromatography method for quantitative determination of oenothein B and quercetin glucuronide in aqueous extract of Epilobii angustifolii herba. J Chromatogr A 1173:146-150. https:// doi.org/10.1016/j.chroma.2007.10.019

Bzducha A, Wołosiak R (2006) Synergistic effect of antioxidant activity of casein and its enzymatic hydrolysate in combination with ascorbic acid and $\beta$-carotene in model oxidation system. Acta Sci Pol Technol Aliment 5:113-133

Chen SL, Yu H, Luo HM, Wu Q, Li CF, Steinmetz A (2016) Conservation and sustainable use of medicinal plants: problems, progress, and prospects. Chin Med 11:37. https://doi.org/10.1186/s1302 0-016-0108-7

Deliu C, Coste A, Mircea T (2013) Epilobium sp. (Willow Herb): micropropagation and production of secondary metabolites. In: Chandra S (ed) Biotechnology for medicinal plants. Springer, Berlin

Deng L, Zong W, Tao X, Liu S, Feng Z, Lin Y, Liao Z, Chen M (2019) Evaluation of the therapeutic effect against benign prostatic hyperplasia and the active constituents from Epilobium angustifolium L. J Ethnopharmacol 232:1-10. https://doi.org/10.1016/j. jep.2018.11.045

Dreger M, Wegenke J, Makowiecka J, Wielgus K (2016) Application of multi-shoots cultures in micropropagation of willowherb (Chamaenerion angustifolium (L.) Scop. Herba Pol 62:28-39. https://doi.org/10.1515/hepo-2016-0015

European Medicines Agency (EMA) (2015) Committee on Herbal Medicinal Products. European Union herbal monograph on Epilobium angustifolium L. and/or Epilobium parviflorum Schreb., herba. https://www.ema.europa.eu/documents/herbal-summary/ willow-herb-summary-public_en.pdf. Accessed 6 Oct 2020.

Figueiredo SFL, Albarello N, Campos Viana VR (2001) Micropropagation of Rollinia mucosa (JACQ.) baill. Vitro Cell Dev Biol 37:471-475. https://doi.org/10.1007/s11627-001-0083-1

Galuszka P, Frébortová J, Luhová L, Bilyeu KD, English JT, Frébort I (2005) Tissue localization of cytokinin dehydrogenase in maize: possible involvement of quinone species generated from plant phenolics by other enzymatic systems in the catalytic reaction. Plant Cell Physiol 46:716-728. https://doi.org/10.1093/pcp/pci07

Granica S, Bazylko A, Kiss AK (2012) Determination of macrocyclic ellagitannin oenothein B in plant materials by HPLC-DAD-MS: method development and validation. Phytochem Anal 23:582587. https://doi.org/10.1002/pca.2358

Gryszczyńska A, Dreger M, Piasecka A, Kachlicki P, Witaszak N, Sawikowska A, Ożarowski M, Opala B, Łowicki Z, Pietrowiak A, Miklaś M, Mikołajczak P, Wielgus K (2018) Qualitative and quantitative analyses of bioactive compounds from ex vitro Chamaenerion angustifolium (L.) (Epilobium augustifolium) herb in different harvest times. Ind Crops Prod 123:208-220. https:// doi.org/10.1016/j.indcrop.2018.06.010

Guo W, Yang J, Sun XD, Chen GJ, Yang YP, Duan YW (2016) Divergence in eco-physiological responses to drought mirrors the distinct distribution of Chamerion angustifolium cytotypes in the Himalaya-Hengduan Mountains region. Front Plant Sci 7:1329. I https://doi.org/10.3389/fpls.2016.01329

Hammond SD, Viehmannova I, Zamecnik J, Panis B, Cepkova PH (2019) Efficient slow-growth conservation and assessment of clonal fidelity of Ullucus tuberosus Caldas microshoots. Plant Cell Tissue Organ Cult 138:559-570. https://doi.org/10.1007/ s11240-019-01653-z

Hatano T, Kusuda M, Inada K, Ogawa T, Shiota S, Tsuchiya T, Yoshida $\mathrm{T}$ (2005) Effects of tannins and related polyphenols on methicillin-resistant Staphylococcus aureus. Phytochem 66:2047-2055. https://doi.org/10.1016/j.phytochem.2005.01.013

Hevesi TB, Blazics B, Kéry Á (2009) Polyphenol composition and antioxidant capacity of Epilobium species. J Pharm Biomed Anal 49:26-31. https://doi.org/10.1016/j.jpba.2008.09.047

Husband BC, Schemske DW (1998) Cytotype distribution at a diploid-tetraploid contact zone in Chamerion (Epilobium) angustifolium (Onagraceae). Am J Bot 85:1688-1694. https://doi. org/10.2307/2446502

Husband BC, Schemske DW (2000) Ecological mechanisms of reproductive isolation between diploid and tetraploid Chamerion angustifolium. J Ecol 88:689-701. https://doi.org/10.104 6/j.1365-2745.2000.00481.x

Irshad I, Kanekanian A, Peters A, Masud T (2015) Antioxidant activity of bioactive peptides derived from bovine casein hydrolysate fractions. J Food Sci Technol 52:231-239. https://doi.org/10.1007/ s13197-012-0920-8

Joo SJ, Yoon AR, Kim YG, Moon BC, Komakech R, Kang Y (2019) In vitro propagation of Trichosanthes kirilowii Maxim. through nodal segment shoot proliferation. In Vitro Cell Dev Biol 55:702709. https://doi.org/10.1007/s11627-019-10010-w

Jürgenson S, Matto V, Raal A (2012) Vegetational variation of phenolic compounds in Epilobium angustifolium. Nat Prod Res 26:19511953. https://doi.org/10.1080/14786419.2011.643310

Kikowska M, Thiem B, Szopa A, Klimek-Szczykutowicz M, Rewers M, Sliwinska E, Ekiert H (2019) Comparative analysis of phenolic acids and flavonoids in shoot cultures of Eryngium alpinum L.: an endangered and protected species with medicinal value. Plant Cell Tissue Organ Cult 139:167-175. https://doi.org/10.1007/ s11240-019-01674-8

Kiss AK, Bazylko A, Filipek A, Granica S, Jaszewska E, Kiarszys U, Kośmider A, Piwowarski J (2011) Oenothein B's contribution to the anti-inflammatory and antioxidant activity of Epilobium sp. Phytomedicine 18:557-560. https://doi.org/10.1016/j.phyme d.2010.10.016

Ko WH, Su CC, Chen CL, Chao CP (2009) Control of lethal browning of tissue culture plantlets of Cavendish banana cv. Formosana with ascorbic acid. Plant Cell Tissue Organ Cult 96:137-141. https://doi.org/10.1007/s11240-008-9469-7 
Kosalec I, Kopjar N, Kremer D (2013) Antimicrobial activity of willowherb (Epilobium angustifolium L.) leaves and flowers. Curr Drug Targets 14(9):986-991. https://doi.org/10.2174/1389450111 3149990177

Kunikowska A, Byczkowska A, Doniak M, Kaźmierczak A (2013) Cytokinins résumé: their signaling and role in programmed cell death in plants. Plant Cell Rep 32:771. https://doi.org/10.1007/ s00299-013-1436-z

Leng P, Su S, Wei F, Yu F, Duan Y (2009) Correlation between browning, total phenolic content, polyphenol oxidase and several antioxidation enzymes during Pistachio tissue culture. Acta Hortic 82:127-132. https://doi.org/10.17660/ActaHortic.2009.829.17

Li Y, Wang X, Chen J, Cai N, Zeng H, Qiao Z, Wang X (2015) A method for micropropagation of Cornus wilsoniana: an important biofuel plant. Ind Crops Prod 76:49-54. https://doi.org/10.1016/j. indcrop.2015.06.042

Łuczkiewicz M, Piotrowski A (2005) Two-stage system for micropropagation of several Genista plants producing large amounts of phytoestrogens. Z Naturforsch C J Biosci 60(7-8):557-566. https ://doi.org/10.1515/znc-2005-7-808

Martin SL, Husband BC (2013) Adaptation of diploid and tetraploid Chamerion angustifolium to elevation but not local environment. Evolution 67:1780-1791. https://doi.org/10.1111/evo.12065

Moilanen J, Salminen J (2008) Ecologically neglected tannins and their biologically relevant activity: chemical structures of plant ellagitannins reveal their in vitro oxidative activity at high $\mathrm{pH}$. Chemoecology 18:73-83. https://doi.org/10.1007/s00049-007-0395-7

Moilanen J, Karonen M, Tähtinen P, Jacquet R, Quideau S, Salminen J (2016) Biological activity of ellagitannins: effects as anti-oxidants, pro-oxidants and metal chelators. Phytochemistry 125:6572. https://doi.org/10.1016/j.phytochem.2016.02.008

Murashige T, Skoog F (1962) A revised medium for rapid growth and bioassays with tobacco tissue cultures. Physiol Plantarum 15:473-497. https://doi.org/10.1111/j.1399-3054.1962.tb08052.x

Murata M, Sugiura M, Sonokawa Y, Shimamura T, Homma S (2002) Properties of chlorogenic acid quinone: relationship between browning and the formation of hydrogen peroxide from a quinone solution. Biosci Biotech Biochem 66:2525-2530. https:// doi.org/10.1271/bbb.66.2525

Niemann MCE, Weber H, Hluska T, Leonte G, Anderson SM, Novák O, Senes A, Werner T (2018) The cytokinin oxidase/dehydrogenase CKX1 is a membrane-bound protein requiring homooligomerization in the endoplasmic reticulum for its cellular activity. Plant Physiol 176:2024-2039. https://doi.org/10.1104/ pp. 17.00925

Norton ME, Norton CR (1985) In vitro propagation of Ericaceae: a comparison of the activity of the cytokinins N6-benzyloadenine and N6-isopentenyladenine in shoot proliferation. Sci Hortic 27:335-340. https://doi.org/10.1016/0304-4238(85)90038-X

Rady MR, Nazif NM (2005) Rosmarinic acid content and RAPD analysis of in vitro regenerated basil (Ocimum americanum) plants. Fitoterapia 76:525-533. https://doi.org/10.1016/j.fitot e.2005.04.001

Ruszová E, Cheel J, Pávek S, Moravcová M, Hermannová M, Matějková I, Spilková J, Velebný V, Kubala L (2013) Epilobium angustifolium extract demonstrates multiple effects on dermal fibroblasts in vitro and skin photo-protection in vivo. Gen Physiol Biophys 32:347-359. https://doi.org/10.4149/gpb_2013031

Schepetkin IA, Ramstead AG, Kirpotina LN, Voyich JM, Jutila MA, Quinn MT (2016) Therapeutic potential of polyphenols from Epilobium angustifolium (fireweed). Phytother Res 30(8):1287-1297. https://doi.org/10.1002/ptr.5648

Szopa A, Ekiert H (2014) Production of biologically active phenolic acids in Aronia melanocarpa (Michx). Elliott in vitro cultures cultivated on different variants of the Murashige and Skoog medium. Plant Growth Regul 72:51-58. https://doi.org/10.1007/ s10725-013-9835-2

Tang W, Harris LC, Outhavong V, Newton RJ (2004) Antioxidants enhance in vitro plant regeneration by inhibiting the accumulation of peroxidase in Virginia pine (Pinus virginiana Mill.). Plant Cell Rep 22:871-877. https://doi.org/10.1007/s00299-004-0781-3

Taniguchi S, Imayoshi Y, Hatano T, Yazaki K, Yoshida T (2002) Hydrolysable tannin production in Oenothera tetraptera shoot tissue culture. Plant Biotechnol 19:357-363. https://doi.org/10.5511/ plantbiotechnology.19.357

Thompson KA, Husband BC, Maherali H (2014) Climatic niche differences between diploid and tetraploid cytotypes of Chamerion angustifolium (Onagraceae). Am J Bot 101:1868-1875. https:// doi.org/10.3732/ajb.1400184

Tita B, Abdel-Haq H, Vitalone A, Mazzanti G, Saso L (2001) Analgesic properties of Epilobium angustifolium, evaluated by the hot plate test and the writhing test. Farmaco 56:341-343. https://doi. org/10.1016/S0014-827X(01)01046-1

Turker AU, Mutlu EC, Yıldırım AB (2008) Efficient in vitro regeneration of fireweed, a medicinal plant. Acta Physiol Plant 30:421426. https://doi.org/10.1007/s11738-008-0136-8

Wagner WL, Hoch PC, Raven PH (2007) Revised classification of the Onagraceae. Syst Bot Monogr 83:1-240. https://repository.si. edu/bitstream/handle/10088/7611/bot_Wagner_et_al_2007-Onagr aceae-sm.pdf?sequence $=1$ \&isAllowed $=y$

Werner T, Köllmer I, Bartrina I, Holst K, Schmülling T (2006) New insights into the biology of cytokinin degradation. Plant Biol 8:371-381. https://doi.org/10.1055/s-2006-923928

Xu CJ, Li H, Li L (2007) Phenylalanine ammonialyase (PAL) gene expression correlated with Phalaenopsis sp. leaf explant browning. J Trop Subtrop Bot 15:50-54. https://doi.org/10.3969/j. issn.1005-3395.2007.1.009

Yoshida T, Yoshimura M, Amakura Y (2018) Chemical and biological significance of oenothein B and related ellagitannin oligomers with macrocyclic structure. Molecules 23:552. https://doi. org/10.3390/molecules23030552

Publisher's Note Springer Nature remains neutral with regard to jurisdictional claims in published maps and institutional affiliations. 